Journal of Anatolian Environmental and Animal Sciences

(Anadolu Çevre ve Hayvancılık Bilimleri Dergisi)

DOI: https://doi.org/10.35229/jaes.700940

\title{
Possible Efficacy of Some Plant Crude Extracts Against Orosanga japonica (Hemiptera: Ricaniidae) Nymphs
}

\author{
İbrahim GUNEY $^{1} \quad$ Murat OZTURK $^{1} \quad$ Asu USTA $^{* 2} \quad$ M. Mustafa AKINER ${ }^{1}$ \\ ${ }^{I}$ Recep Tayyip Erdoğan University, Faculty of Arts and Sciences, Department of Biology, 53100 Rize, Turkey \\ ${ }^{2}$ Recep Tayyip Erdoğan University, Faculty of Arts and Sciences, Department of Chemistry, 53100 Rize, Turkey.
}

How to cite: How to cite: Guney, İ., Ozturk, M., Usta, A. \& Akıner, M.M. (2020). Possible Efficacy of Some Plant Crude Extracts Against Orosanga japonica (Hemiptera: Ricaniidae) Nymphs. J. Anatolian Env. and Anim. Sciences, 5(2), 191-198.

Atıf yapmak için: Guney, İ., Ozturk, M., Usta, A. \& Akıner, M.M. (2020). Bazı Bitki Ham Özütlerinin Orosanga japonica (Hemiptera: Ricanidae) Nimflerine Karşı Olası Etkinlikleri. Anadolu Çev. ve Hay. Dergisi, 5(2), 191-198.

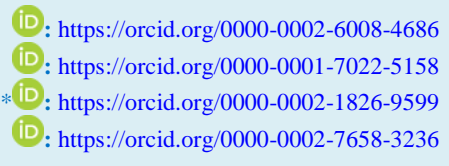

*Corresponding author's:

Asu USTA

Recep Tayyip Erdoğan University, Faculty of Arts and Sciences, Department of Chemistry, 53100 Rize, Turkey.

\: asu.usta@erdogan.edu.tr

Mobile telephone : +90 (532) 5409553

Telephone $\quad:+90(464) 2236126$

Fax $\quad:+90(464) 2234019$
Abstract: In this study, twenty species from twelve plant families were tested for potential effectiveness against Orosanga japonica control on nymph. Methanol extracts mortality rates were generally found to be higher than ethyl acetate extracts. Most effective plant crude extracts were Salvia verticillate (Lamiaceae) and Daucus carota (Apiaceae) respectively. Consequently, we reported the high or moderate potential insecticidal activity against Orosanga nymphs from eleven different plant families extract. That is why, we recommend extensive and more detailed study for the establish biological based control methods against invasive Orosanga japonica in Black Sea countries.

Keywords: Biological control, insecticidal activity, mortality, Orosanga japonica, plant extract, Ricaniidae, Turkey.

\section{Bazı Bitki Ham Özütlerinin Orosanga japonica (Hemiptera: Ricanidae) Nimflerine Karşı Olası Etkinlikleri}

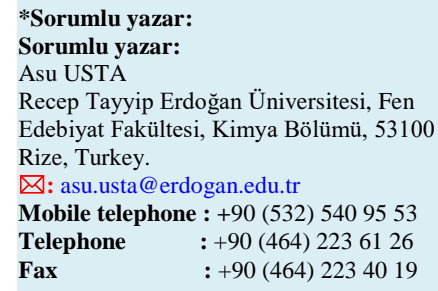
Fax : $+90(464) 2234019$

Öz: Bu çalışmada, on iki bitki familyasından yirmi türün Orosanga japonica nimf kontrolüne karşı potansiyel etkinlikleri edilmiştir. Metanol ekstraktları ölüm oranlarının genellikle etil asetat ekstraktlarından daha yüksek olduğu bulunmuştur. En etkili bitki ham özütleri sırasıyla Salvia verticillate (Lamiaceae) ve Daucus carota (Apiaceae) olarak görülmüştür. Sonuç olarak, on bir farklı bitki familyası türlerinden alınan özütlerin Orosanga nimflerine karşı yüksek veya orta derecede potansiyel insektisidal aktivite rapor edilmiştir. Bu nedenle Karadeniz ülkelerinde istilacı Orosanga japonica'ya karşı biyolojik bazlı kontrol yöntemlerinin oluşturulması için kapsamlı ve daha ayrıntılı bir çalışma yapılması gerekmektedir.

$\underline{\text { Anahtar kelimeler: Biyolojik kontrol, insektisidal aktivite, ölüm oranı, Orosanga japonica, bitki }}$ özütü, Ricaniidae, Türkiye. 


\section{INTRODUCTION}

Ricaniidae species have an important group in the Hemipteran pests that include invasive species. This family is represented in the world with 46 genera and 450 species. (Chou et al., 1985; Shcherbakov, 2006; Gnezdilov, 2009; Bu et al. 2010). Only species belonging to the Ricania genus of this family are distributed in Palaearctic Region (Demir, 2009). However, some Ricaniidae species have spread to beyond to the original habitats. Orosanga japonica was firstly detected in Russia (Krasnodar), Ukraine (Crimea) in West Palearctic. It was transported from native habitats to Russia in the 1900s via seedling or plants transportation for the Botanical garden. In 1950s, the species was recorded in Georgia (Nast, 1987; Gnezdilov \& Sugonyaev, 2009; EPPO, 2016; Bourgoin, 2017). For the last two decades, it has been reported in the Eastern Black Sea area and began to spread rapidly to the west (Demir, 2009; Cebir, 2016; Demir, 2018; Akıner et al., 2019). It was also recorded in the Western Black Sea region by Öztemiz, (2018) and İstanbul by Arslangündoğdu \& Hizal, (2019). Adult and nymph stages of this species are fed with plant sap like beans, corn, cabbage, pepper and eggplant, especially in all agricultural plants, shrubs and shoots (Gokturk \& Aksu, 2014). Furthermore, they caused indirect by damage on weaken the plant. This situation makes the plant vulnerable to attack by some important plant pathogenic fungi (Cylindrocarpon sp., Fusarium sp. and Pestalotiopsis quepinii) (Eken et al., 2013). O. japonica is an important plant pest, generally in tropical regions but recently some authors reported the different degree of damage situation about chestnut in Abhazia (related to vector situation of the fungus pathogen), orchards in around Caspian Sea in Iran, tea and kiwifruit in Turkey (Lukmazova \& Selikhovkin, 2013; Ak et al., 2015; Mozaffarian, 2018). In recent years, the population of $O$. japonica has increased step by step in the Eastern Black Sea region (Akıner et al., 2019).

Eastern Black Sea is a region characterized by its topographic characteristics and precipitation regime, and it differs from other regions of Turkey. Agricultural production is limited due to the limited cultivable areas and the sloping structure of the land. The most important agricultural products of the region are tea (Camelia sinensis), hazelnut (Corylus avellana) and kiwi (Actinidia deliciosa), respectively. The increase in $O$. japonica population level and its rapid spread are arised problems in the agriculture of these commercial products and cause production losses. Pest has an important detrimental effect on different plants grown such as Vitis vinifera, Ficus carica, Phaseolus vulgaris and Cucumis sativus. According to the decision of Turkey's General Directorate of Tea Enterprises, step by step, also including fertilizers are applied zero synthetic chemicals in the region. Therefore, chemical control agent (insecticides) usage is very limited in the Eastern Black Sea area though.
In this mean, the area is the only region in the world where tea plant grows in naturally without any input except limited amount of chemical fertilizer.

The long term control of Ricanidae species with insecticides has yet been developed in any country (Jeon et. al., 2017). Synthetic insecticide based control methods are most influential method for pest control in many areas (human, animal and plant health). But, the use of synthetic chemicals is known to bring serious problems such as environmental contamination and insecticide resistance (Nicoletti e al., 2010; Liu et al., 2012). Additionally, toxic and detrimental effects on non target organisms are very big problem in many areas (Dinesh et al., 2015).There is a need to develop selective and naturally-based control methods in the control of the Ricaniidae species due to the harmful effects of chemical based insecticides and above mentioned reasons. Botanical based materials are safer for non target organisms and environmentally friendly agents for pest control operations (Lee \& Lee, 2016; Lee et al., 2016). Although different kinds of biological based control agents and mechanical control option studies were conducted against adult stage of $O$. japonica (Güçlü et al., 2010; Ak et al., 2013; Eken et al., 2013; Gokturk \& Mihl1, 2015; Gokturk et al., 2017), there is a need more study of subject.

All of the selected plants are belonging to some plant families identified as to have a significant insecticidal and larvicidal activity against different kind of insects. Around 110 plant families with these properties have been identified worldwide and Lamiaceae, Fabaceae, Asteraceae, Apiaceae and, Solanaceae are the most important families in this group (Boulogne et al., 2012). Similar studies for different insect are usually about obtaining essential oils by hydrodistillation method and investigating their insecticidal properties. In this study, examined the possible efficacy of different plant crude extracts against nymph stage of $O$. japonica. Therefore, firstly, our aim in this study is to investigate the contact toxicity of crude extracts derived from a plant twenty naturally grown in Turkey.

\section{MATERIAL AND METHOD}

Plant material: Selected twenty plant species were collected from different localities in Turkey. The specimen identification was performed by Prof. Vagif Atamov from the Faculty of Science and Arts, Recep Tayyip Erdogan University in Rize, Turkey. A sample of each plant was deposited in the Herbarium of Biology Department. Information about these plants are given in Table 1 .

Preparation of plant extracts: During the extraction of plants, it is important to avoid contamination of the extract as a result of extraction conditions or solvent impurities. The aerial parts of fresh plants were cleaned and 
washed with distilled water and ethyl alcohol mixture against fungus like contaminations $(1: 1, \mathrm{v} / \mathrm{v})$. Cleaned plant materials were dried for one week at room temperature with reduced humidity $(25 \%)$. Subsequently, all materials were powdered using an electric blender and made as in the literatıre by ethyl acetate and methanol (Dmitrienko et al., 2012; Mokrani \& Madani, 2016). The crude extracts were filtered, evaporated to dryness and lyophilized under pressure to completely remove the solvent used in the extraction. A stock solution of each crude extract was prepared in DMSO and stored below $4{ }^{\circ} \mathrm{C}$ until testing for bioassay. Crude oil yields obtained from extractions with a solvent of studied plant materials are given in Table 1.

Table 1. Crude oil yields obtained from extractions with a solvent of studied plant materials

\begin{tabular}{|c|c|c|c|c|c|c|}
\hline \multirow{2}{*}{ Family } & \multirow{2}{*}{ Plant species } & \multirow{2}{*}{ Date } & \multirow{2}{*}{ Origin } & \multirow{2}{*}{ Used part } & \multicolumn{2}{|c|}{ Yield (\%) } \\
\hline & & & & & $\mathrm{MeOH}$ & EtOAc \\
\hline \multirow{3}{*}{ Lamiacae } & Salvia vertisillate & May 2018 & Antalya & Aerial part & 7.80 & 2.93 \\
\hline & Phlomis lychitis & May 2018 & Konya & Aerial part & 9.71 & 2.46 \\
\hline & Salvia tomentosa & May 2018 & Antalya & Aerial part & 8.07 & 6.43 \\
\hline \multirow{2}{*}{ Apiaceae } & Foeniculum vulgare & July 2018 & Denizli & Aerial part & 5.30 & 1.62 \\
\hline & Daucus carota & Aug. 2018 & Rize & Aerial part & 5.98 & 3.12 \\
\hline \multirow{5}{*}{ Asteraceae } & Matricaria chamomilla & May 2018 & Denizli & Aerial part & 2.34 & 6.71 \\
\hline & Laucantheum vulgare & April 2018 & Rize & Aerial part & 3.67 & 3.68 \\
\hline & Tripleurospermum vulgare & May 2018 & Rize & Aerial part & 6.97 & 4.03 \\
\hline & Erigeron annuus & June 2018 & Rize & Aerial part & 4.55 & 2.23 \\
\hline & Inula vulgaris & Sept. 2018 & Artvin & Aerial part & 2.78 & 3.33 \\
\hline \multirow{2}{*}{ Primulaceae } & Primula vulgaris & April 2019 & Artvin & Flower & 10.99 & 3.53 \\
\hline & Primula vulgaris & April 2019 & Artvin & Leaf & 12.69 & 2.64 \\
\hline \multirow{2}{*}{ Ericaceae } & Rhododendron luteum & Aug. 2018 & Rize & Flower & 2.27 & 0.86 \\
\hline & Rhododendron ponticum & June 2018 & Rize & Leaf & 1.16 & 1.26 \\
\hline Rutaceae & Citrus sinensis & Febr. 2018 & Rize & Fruit peel & 1.36 & 1.16 \\
\hline Lauraceae & Laurus nobilis & April 2018 & Denizli & Leaf & 5.59 & 3.66 \\
\hline Solonaceae & Nicotiana tabacum & Aug. 2018 & Denizli & Leaf & 5.23 & 5.73 \\
\hline Polygonaceae & Polygonum persicaria & Sept.2018 & Rize & Aerial part & 2.91 & 1.03 \\
\hline Papaveraceae & Papaver somniferum & May 2018 & Konya & Seed & 6.68 & 12.57 \\
\hline Lythraceae & Lythrum salicaria & Sept. 2018 & Rize & Aerial part & 7.05 & 3.71 \\
\hline Boraginaceae & Heliotropium europaeum & July 2018 & Antalya & Aerial part & 5.84 & 3.82 \\
\hline \multicolumn{7}{|c|}{ MeOH: Methyl alcohol; EtOAc: Ethyl acetate } \\
\hline \multicolumn{7}{|c|}{ 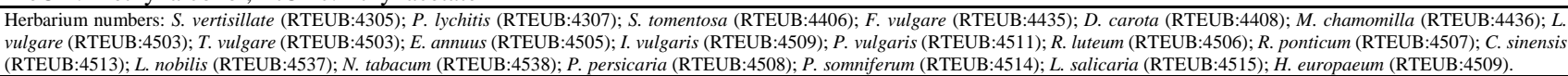 } \\
\hline
\end{tabular}

\section{Test organisms}

The nymphs of $O$. japonica were collected with electric aspirator in and around Rize city (41.025461 Lat 40.482803 Lon Alipasa, 41.036468 Lat 40.493461 Lon Campus). About 1000 Orosanga nymphs collected from region were placed into the cages $(20 \times 20 \times 20 \mathrm{~cm}$, maximum of 50 nymphs) and transferred to the laboratory. The samples brought to the insectarium were taken into cages of $50 \times 50 \times 50 \mathrm{~cm}$ for easy to feed (maximum of 100 nymphs in each cage) during acclimatisation period. The cages to be used were previously sterilised in order to avoid any contamination. Samples were held at $26 \pm 2{ }^{\circ} \mathrm{C}, 65 \pm$ $10 \%$ relative humidity and a photoperiod regime of $12: 12$ $\mathrm{h}$ (L:D) in the insectarium. Fresh blackberry branches were put into the cages for feeding. Samples were kept for 24 hours in the insectarium for to acclimate to the environment before the tests.

\section{Insecticidal Activity}

$250 \mathrm{~mL}$ glass jars and filter paper were used for evaluating the contact toxicity of crude extracts. The each of stock solutions (500 ppm) prepared by using DMSO was impregnated to filter papers $(10 \times 20 \mathrm{~cm})$ prepared separately. DMSO impregnated paper was used as a control. Filter papers were placed in the jars after impregnation. Glass jar was cleaned and autoclaved before experiment. Collected and acclimatised $O$. japonica nymphs for 24 hours were distributed to $250 \mathrm{~mL}$ glass jars. 20 individuals were used for every test chamber for avoiding uncontrolled death rate related to the density effect. Fresh blackberry branch was put into every jar for feeding.

24 hours and 48 hours death rate were counted. The per cent mortality was calculated according to the death rate and corrected Abbott formula (Abbott, 1925). All tests were done in two replications.

\section{RESULTS AND DISCUSSION}

In this study, 20 species from eleven plant families were tested for potential efficacy against nymph stage of $O$. japonica was evaluated by contact toxicity assay by using impregnated paper (Table 2). The effect rate (death rate) of two kinds of crude extracts obtained by using different polarity solvents such as ethyl acetate and methyl alcohol varies between 2.5 and 100 per cent. 
Table 2. The effectiveness of different plants crude extracts against nymph stage of $O$. japonica

\begin{tabular}{|c|c|c|c|c|c|}
\hline \multirow{3}{*}{ Family } & \multirow{3}{*}{ Plant species } & \multicolumn{4}{|c|}{$\%$ mortality } \\
\hline & & \multicolumn{2}{|c|}{ EtOAc } & \multicolumn{2}{|c|}{$\mathrm{MeOH}$} \\
\hline & & $24 \mathrm{~h}$ & $48 \mathrm{~h}$ & $24 \mathrm{~h}$ & $48 \mathrm{~h}$ \\
\hline \multirow{3}{*}{ Lamiacae } & Salvia vertisillate & 80 & 100 & 87.50 & 100 \\
\hline & Phlomis lychitis & 17.50 & 56.25 & 16.25 & 71.25 \\
\hline & Salvia tomentosa & 33.75 & 55 & 35 & 81.25 \\
\hline \multirow{2}{*}{ Apiaceae } & Foeniculum vulgare & 33.75 & 52.5 & 27.50 & 53.75 \\
\hline & Daucus carota & 87.75 & 100 & 78.75 & 100 \\
\hline \multirow{5}{*}{ Asteraceae } & Matricaria chamomilla & 8.75 & 87.5 & 2.50 & 2.50 \\
\hline & Leucanthemum vulgare & 18.75 & 47.5 & 25 & 75 \\
\hline & Tripleurospermum caucasicum & 20 & 43.75 & 71.25 & 98.75 \\
\hline & Erigeron annuus & 65 & 82.5 & 73.75 & 100 \\
\hline & Inula vulgaris & 22.50 & 48.75 & 18.75 & 66.25 \\
\hline \multirow{2}{*}{ Primulaceae } & Primula vulgaris (flower) & 52.5 & 90.25 & 56.25 & 96.25 \\
\hline & Primula vulgaris (leaf) & 32.5 & 86.25 & 61.25 & 98.75 \\
\hline \multirow{2}{*}{ Ericaceae } & Rhododendron luteum & 31.25 & 76.25 & 30 & 76.25 \\
\hline & Rhododendron ponticum & 51.25 & 82.5 & 52.5 & 80 \\
\hline Rutaceae & Citrus sinensis & 61.25 & 90 & 72.5 & 98.75 \\
\hline Lauraceae & Laurus nobilis & 70 & 95 & 53.75 & 91.25 \\
\hline Solonaceae & Nicotiana tabacum & 22.50 & 61.25 & 27.50 & 72.5 \\
\hline Polygonaceae & Polygonum persicaria & 23.75 & 60 & 36.25 & 77.5 \\
\hline Papaveraceae & Papaver somniferum & 47.75 & 80 & 30 & 60 \\
\hline Lythraceae & Lythrum salicaria & 57.5 & 96.25 & 67.5 & 93.75 \\
\hline Boraginaceae & Heliotropium europaeum & 38.75 & 93.75 & 66.25 & 98.75 \\
\hline h: hour; $\mathrm{MeOH}$ & ol; EtOAc: Ethyl acetate & & & & \\
\hline
\end{tabular}

Among the tested species in the Lamiaceae family, Salvia vertisillate caused the highest mortality rates after 24 and $48 \mathrm{~h}$ periods for two tested extract types. Salvia tomentosa and Phlomis lychitis caused high mortality rates after $48 \mathrm{~h}$ test period for two tested extract types. EtOAc extract gave 52.5-55\% mortality values for this two plant species after 48 h. For Apiaceae family, Daucus carota caused high mortality for two extract types after 24 and 48 $\mathrm{h}$ and mortality values ranged between $78.75 \%$ (MeOH 24 h) and $100 \%$ (EtOAc and $\mathrm{MeOH} 48 \mathrm{~h}$ ). In contrast this result Foeniculum vulgare caused low mortality for all tested periods and extract types. Asteraceae family plant species test results ranged between $2.5 \%$ (Matricaria camomilla $\mathrm{MeOH}$ extract $24 \mathrm{~h}$ ) and $100 \%$ (Erigeron annuus $\mathrm{MeOH}$ extract 48 h). E. annuus caused highest mortaliy after two tested periods and extract types among the tested Asteracea family species. Only one species tested from the Primulaceae family member, but two different plant parts tested (flower and leaf). Whole tested design caused moderate and high mortality after 24 and 48 h except EtOAc leaf extract $24 \mathrm{~h}$ tested period (32.5\%) for Primula vulgaris. Rhododendron ponticum caused moderate and high mortality rates for two tested periods and extracts. Rhododendron luteum caused high mortality for two tested extracts $48 \mathrm{~h}$ after the test. Alhough two Ericaceae species gave moderate and high mortality, it did not exceed $82.5 \%$ (EtOAc extract 48 h). Citrus sinensis (Rutaceae), Laurus nobilis (Lauraceae), Lythrum salicaria (Lythraceae) and Heliothropium europium (Boraginaceae) species extracts caused moderate and high mortality rates after both extract types and tested periods among the other tested plant family members.
In general, methyl alcohol extracts mortality rates were generally found higher than ethyl acetate extracts. It was determined that the most effective plant extracts against $O$. japonica nymphs were $S$. verticillate (Lamiaceae) and D. carota (Apiaceae) for two extracts and two intervals after experiment (24-48 h). Duration times increased the mortality rates except $M$. camomilla (Asteraceae) methanol extract. Although M. camomilla methyl alcohol extract mortality rates were the same, the highest increase of mortality rates was found in ethyl acetate extract for this plant.

Some authors reported the effective activity range for Salvia species against vector mosquito species larvae, biting deterrent activity (Ali et al., 2014; Gün et al., 2011) and plant pest species (Kara et al., 2014; Kostic et al., 2007). Our results showed moderate or high mortality rates for two different Salvia species, but $S$. tomentosa activity was lower than the $S$. verticillate. Salvia species include high rate of different terpenoid and sesquiterpenoid components according to the some studies about the chemical composition (Sefidkon \& Khajavi, 1999; Tabanca et al., 2017). Chemical composition of the plant species related to the insecticidal activity refers to terpenoids, alkoloids and phenolic compounds (Boulogne \& Petit, 2012). Furthermore, methyl alcohol and ethyl acetate are the best solvents for the phenolic, terpenoid and flavonoid constitutients respectively (Dimitrienko et al., 2012; Mokrani \& Madani, 2016). The last Lamiaceae member of this study ( $P$. lychitis) caused low and moderate mortality during $24 \mathrm{~h}$ and $48 \mathrm{~h}$. Although chemical composition of the Phlomis species include different degree of sesquiterpene and terpenoid, this result may be explained by lower ratio of terpenoid than Salvia species 
(Lopez et al., 2010; Sarıkaya \& Fakir, 2017). Some studies refer to $D$. carota extracts for effectiveness against different plant pest species and mosquito groups (El Idrisii, 2016; Hrudova et al., 2006; Muturi et al., 2019). Muturi et al., (2019) indicated that three chemical constitutents (terpinolene, para cymene, and $\gamma$-terpinene) have more toxic than the other six tested chemical compositions. Our results gave high efficiency against nympheal stages of the $O$. japonia. Although D. carota extracts gave high mortality rates, other Apiaceae species ( $F$. vulgare) caused low and moderate mortality after $24 \mathrm{~h}$ and $48 \mathrm{~h}$ duration. Some studies reported the high constituent of tepenoid compound and antifungal acitivity for $F$. vulgare, but our results did not indicate high insecticidal activity (Diao et al., 2014; Dukc et al., 2003). Five Asteraceae species caused moderate or high mortaliy rates during $48 \mathrm{~h}$ duration except $M$. camomilla methyl alcohol extract. Asteraceae family reported as the third family that showed insecticidal activity (Boulogne \& Petit, 2012). Our results indicated that methyl alcohol extracts for Asteraceae species are more effective than ethyl acetate extracts. $P$. vulgaris leaf and flower extracts showed moderate and high activity against nymph. Death rate of $48 \mathrm{~h}$ gave up to $86 \%$ and high potential of the insecticidal activity. Methyl alcohol extract mortality rates were higher than the ethyl acetate extract. It was reported that the high phenolic, monoterpene and terpene like compounds $P$. vulgaris and other Primula species (Yaylı et al., 2016; Baczek et al., 2017). Therefore, high insecticidal activity may be related to this compounds in crude extracts. Two different Ericaceae species were tested in this study and results showed that the moderate or high mortality after $48 \mathrm{~h}$. Chemical constituents of $R$. luteum and $R$. ponticum include different degree of terpenoid and phenolic compounds (Tasdemir et al., 2003; Usta et al., 2012). This constituent may be related to the higher toxicity of the nymphs, but does not completely explain these results. Giatropoulos et al., (2012) reported the larvicidal effects against the mosquito Aedes albopictus and relation to the limonene and pinene in the essential oils. Furthermore, essential oil of fruit peels and seeds of $C$. sinensis killed the larvae and adults of Triboluim castaneum by contact action (Salem et al., 2013). In our study, C. sinensis gave mortality up to $61 \%$ for 24 and 48 h duration. Our results revealed that $C$. sinensis was the high potential of the control. L. nobilis is one of the very well known plant for the tropical and subtropical region. It is known that the bioactive compunds are related to many usage areas such as antibacterial, antifungal, antioxidant and insecticidal (Charal et al., 2017). Our results indicated high insecticidal properties against nymphs. Nicotiana tabacum gave low $(24 \mathrm{~h})$ or moderate $(48 \mathrm{~h})$ toxicity against nymphs. This plant based biological activities against different kind of plant pest caused high mortality Grapholita molesta (Lepidoptera: Tortricidae) (Sarker \& Lim, 2018) and also other Nicatiana species extracts caused $100 \%$ mortality against key insect pests Brassicas (Amoebeng et al., 2018). But our results did not exceed $72.5 \%$ (methyl alcohol 48 h). Polygonum persicaria results showed a similar pattern with $N$. tabacum and gave moderate mortality after $48 \mathrm{~h}$ for two different extraction types. Although terpenoid components of Polygonum species were reported to be high (Saeidnia et al., 2014), insecticidal activities were not consistent with this situation in our result. Papaver somniferum seed extract caused low or moderate mortality after $48 \mathrm{~h}$ duration period. Papaver chemical component is generally related to the drug industry and pharmaceutical benzylisoquinoline alkaloids and terpenoid constituent is not working well (Hao et al., 2015). Therefore constituent of alcohol based extraction may provide moderate toxicity after 48 h. L. salicaria results referred to the high inseciticidal potential. Mortality results were found to be up to $57.5 \%$ for $24 \mathrm{~h}$ and $48 \mathrm{~h}$ results were up to $93.75 \%$. High phenolic compounds to this species (Rouha et al., 2001) were reported and it maybe related to the high potential of the insecticidal activity for this group. $H$. europaeum gave similar results like $L$. salicaria. It was reported the high alcoholic and different degree of flavonoid and triterpenoid constituent Heliothropium species. H. europeaum is also used for folk medicide as antipyretic, antihelmintic, cholagogue, emmenagogue, cardiotonic (Saeedi \& Morteza-Semnani, 2009; Goyal \& Sharma, 2014). Here we evaluated high potential of insecticidal activity.

\section{CONCLUSION}

Here, we reported that a total of 20 different plants distributed into 12 families have high or moderate potential insecticidal activities against $O$. japonica nymphs. Seven family groups are also well known insecticidal properties (Boulogne \& Petit, 2012). Five other families such as Primulaceae, Ericaceae, Papaveraceae, Lythraceae and Boraginaceae were included in the study to see the comparison in terms of their insecticidal activity. It was determined that the plants in this family also show activity against Orosanga nymphs in varying proportions. There is a need for an extensive study about the insecticidal activity and detailed chemical composition related to the this data in near future to establish biological based control methods for this group. Nevertheless, it is thought that the observed activity values will contribute to the elimination of deficiencies in the literature and to create different thoughts on the subject. 


\section{REFERENCES}

Abbott, W.S. (1925) A method of computing the effectiveness of an insecticide. Journal of Economic Entomology, 18, 265-267.

Ak, K., Güçlü, S. \& Sekban, R. (2013). A new pest in East Black Sea Region, Ricania simulans (Walker, 1851) determining effectiveness of biopesticides with active substances of Azadirachtin and Spinosad against (Hemiptera: Ricaniidae). Journal of Agricultural Sciences Research, 6, 10-14.

Ak, K., Güçlü, S., Eken, C. \& Sekban, R. (2015). Türkiye için yeni bir zararlı Ricania simulans (walker, 1851) (Hemiptera: ricaniidae). Türkiye Entomoloji Dergisi. 39, 179-186.

Akıner, M.M., Beriş, F.Ş., Seyis, F., Öztürk, M., Sevgili, H. \& Demir, E. (2019). Annual variation of the Orosanga japonica Melichar 1898 (Hemiptera: Ricaniidae) populations in the eastern Black Sea region of Turkey and possible molecular separation with based on 28S rDNA sequences from other Ricaniidae groups. Plant Protection Bulletin, 59, 11-19.

Amoebeng, B.W., Stevenson, P.C., Pandey, S., Mochiah, M.B. \& Gurr, M.G. (2018). Insecticidal activity of a native Australian tobacco, Nicotiana megalosiphon Van Heurck \& Muell. Arg.(Solanales: Solanaceae) against key insect pests of brassicas. Crop protection, 106, 612.

Arslangündoğdu, Z. \& Hizal, E. (2019). New distribution area and host plants for invasive alien insect species, Orosanga japonica (melichar) in Turkey (Hemiptera: Ricaniidae). Entomologica Americana, 124, 26-30.

Baczek, K., Przybyl, J.L., Mirgos, M., Kosakowska, O., Szymborska-Sandhu, I. \& Weglarz, Z. (2017). Phenolics in Primula veris L. and P. elatior (L.) Hill Raw Materials. International journal of analytical chemistry, Article ID 2871579, 7 pages

Boulogne, I. \& Petit, P. (2012). Insecticidal and antifungal chemicals produced by plants: a review. Environmental chemistry letters, 10, 325-347.

Bourgoin, T. (2017). FLOW (Fulgoromorpha Lists on The web): a world knowledge base dedicated to Fulgoromorpha. Version 8, updated, last update: 06.02.2017. http://hemiptera-databases.org/flow/. (accessed on April 2019).

Bu, C.P., Lariviere, M.C. \& Liang, A.P. (2010). Parapiromis nom. nov., a new name for Piromis Fennah (Hemiptera: Fulgoromorpha: Ricaniidae), with descriptions of three new species. Zootaxa, 2400, 29-40.

Cebir, Y. (2016). Determining of the Ricania japonica population structure that dispersed east Black Sea region and analysis of the systematic situation by molecular methods. (MSc Thesis), Recep Tayyip Erdogan University Graduate School of Natural and Applied Sciences, 61 p., Rize.(Turkish).
Chahal, K.K., Kaur, M., Bhardwaj, U., Singla, N. \& Kaur, A. (2017). A review on chemistry and biological activities of Laurus nobilis L. essential oil. Journal of Pharmacognosy and Phytochemistry, 6, 1153-1161.

Chou, I.J., Huang, J. \& Wang, S. (1985). Economic Insects Fauna of China. Fasc. 36. Homoptera Fulgoroidea. Sciences Press Beijing, China, 1152.

Demir, E. (2009). Ricania Germar, 1818 species of Western Palaearctic Region (Hemiptera: Fulgoromorpha: Ricaniidae). Munis Entomology \& Zoology, 4, 271-275.

Demir, E. (2018). The economically important alien invasive planthoppers in Turkey (Hemiptera: Fulgoromorpha). Acta Entomologica Slovenica, 26, 231-240.

Diao, W.R., Hu, Q.P., Zhang, H. \& Xu, J.G. (2014). Chemical composition, antibacterial activity and mechanism of action of essential oil from seeds of fennel (Foeniculum vulgare Mill.). Food Control, 35, 109-116.

Dinesh, D.S., Kumari, S., Pandit, V., Kumar, J., Kumari, N., Kumar, P., Hassan, F., Kumar, V. \& Das, P. (2015). Insecticidal effect of plant extracts on Phlebotomus argentipes (Diptera: Psychodidae) in Bihar, India. Indian Journal of Medicinal Research, 142, 95-100.

Dimitrienko, S.G., Kudrinskaya, V.A. \& Apyari, V.V. (2012). Methods of extraction, preconcentration, and determination of quercetin. Journal of Analytical Chemistry, 67, 299-311.

Eken, C., Ak, K., Güçlü, S., Genç, T. \& Sekban, R. (2013) Fungal flora of Ricania simulans (Hemiptera: Ricaniidae). XI. National Ecology and Environment Congress (01-04 Sept. 2013, Samsun, Turkey), $208 \mathrm{pp}$.

El Idrissi, M., Elhourri, M., Amecrough, A. \& Lemrhari, A. (2016). Insecticide activity study of essential oils of Daucus carota (L.) ssp. carota and Chenopodium ambrosioides (L.) on white larvae of Melolontha melolontha. International Journal of Environmental Chemistry and Ecotoxicology Research, 1, 12-21.

EPPO. (2016). Ricania japonica: a new polyphagous insect found in the EPPO region (2016/100). European and mediterranean Plant Protection Organization reporting Service no.5 Paris, 201605-Pests, 17-18.

Giatropoulos, A., Papachristos, D.P., Kimbaris, A., Koliopoulos, G., Polissiou, M.G., Emmanouel, N. \& Michaelakis, A. (2012). Evaluation of bioefficacy of three Citrus essential oils against the dengue vector Aedes albopictus (Diptera: Culicidae) in correlation to their components enantiomeric distribution. Parasitology Research, 111, 2253-2263.

Gnezdilov, V.M. \& Sugonyaev, E.S. (2009). First record of Metcalfa pruinosa Homoptera: Fulgoroidea: Flatidae) from Russia. Zoosystematica Rossica, 18, 260-261. 
Gnezdilov, V.M. (2009). A new subfamily of the planthopper family Ricaniidae Amyot et Serville (Homoptera, Fulgoroidea). Entomological Review, 89, 1082-1086.

Gokturk, T. \& Aksu, Y. (2014). Morphology, biology and damage of Ricania simulans (Walker, 1851) (Hemiptera: Ricaniidae), which harms agricultural and forest areas. Turkey II. Forest Entomology and Pathology Symposium (7-9 April 2014), Antalya 279-281.(Turkish).

Gokturk, T. \& Mıhlı, A. (2015). Investigations on struggling with Ricania simulans (Walker) 1851 (Hemiptera: Ricaniidae) an important pest of the Eastern Black Sea Coastlines. Artvin Coruh University Journal of Forestry Faculty, 16, 89-93.

Gokturk, T., Kordalı, S. \& Bozhuyuk, A.U. (2017). Insecticidal effects of essential oils against nymphal and adult stage of Ricania simulans (Hemiptera: Ricanidae). Natural Product Communications, 12, 973-976.

Goyal, N. \& Sharma, S.K. (2014). Bioactive phytoconstituents and plant extracts from genus Heliotropium. International Journal of Green Pharmacy, 8, 217-225.

Güçlü, S., Ak, K., Eken, C., Akyol, H., Sekban, R., Beytut, B. \& Yıldırım, R. (2010). Pathogenicity of Lecanicillium muscarium against Ricania simulans. Bulletin of Insectology, 63, 243-246.

Gün, S.Ş., Çınbılgel, I., Öz, E. \& Çetin, H. (2011). Larvicidal activity of some Salvia L. (Labiatae) plant extract against the mosquito Culex pipiens L. (Diptera: Culicidae). Kafkas Universitesi Veteriner Fakultesi Dergisi, 17, 61-65.

Hao, D.C., Hu, X.L. \& Xiao, P.G. (2015). Phytochemical and biological research of Papaver pharmaceutical resources. Medicinal Plants, 217251. Elsevier Publishing 2015.

Hrudova, E., Kocourková, B. \& Zelená, V. (2006). Insecticidal effect of carrot (Daucus carota) and lovage (Levisticum officinale) (Apiaceae) extracts against Tribolium confusum Jacquelin du Duval, 1868 (Coleoptera, Tenebrionidae). Acta Universitatis Agriculturae et Silviculturae Mendelianae Brunensis, 54, 165-168.

Jeon, Y.J., Lee, S.G., Yang, Y.C. \& Lee, H.S. (2017). Insecticidal activities of their components derived from the essential oils of Cinnamomum sp. barks and against Ricania sp. (Homoptera: Ricaniidae), a newly recorded pest. Pest Management Science, 73, 2000-2004.

Kara, N., Yorulmaz, S.S. \& Baydar, H. (2014). The Usage of Sage (Salvia officinalis L.) and Rosemary (Rosmarinus officinalis L.) Extracts in the Management of Potato Beetle (Leptinotarsa decemlineata Say.). Turkish Journal of Agricultural and Natural Sciences, 1, 248-254.

Kostıc, M., Drazic, S., Popovic, Z., Stankovic, S., Sivcev, I. \& Zivanovic, T. (2007). Developmental and feeding alternations in Leptinotarsa decemlineata Say. (Coleoptera: Chrysomelidae) caused by
Salvia officinalis L. (Lamiaceae) essential oil. Biotechnology and Biotechnological Equipment, 21, 426-430.

Lee, H.K \& Lee, H.S. (2016). Toxicities of active constituent isolated from Thymus vulgaris flowers and its structural derivatives against Tribolium castaneum (Herbst). Applied Biological Chemistry, 59, 821-826.

Lee, H.W., Lee, S.G. \& Lee, H.S. (2016). Active component isolated from Eugenia caryophyllata. Applied Biological Chemistry, 59, 609-614.

Liu, Z.L., Liu, Q.Z., Du, S.S. \& Deng, Z.W. (2012). Mosquito larvicidal activity of alkaloids and limonoids derived from Evodia rutaecarpa unripe fruits against Aedes albopictus (Diptera: Culicidae). Parasitology Research, 111, 991-996.

Lopez, V., Jager, A.K., Akerrata, S., Cavero, R.Y. \& Calvo, M.I. (2010). Antioxidant activity and phenylpropanoids of Phlomis lychnitis L.: A traditional herbal tea. Plant Foods for Human Nutrition, 65, 179-185.

Lukmazova, E.A. \& Selikhovkin, A.V. (2013). Forest Pest Status of Chestnut Forests of the Abkhazia republic. International Caucasian Forestry Symposium, 24-26 October 2013, Artvin, Turkey.

Mımıca-Dukiç, N., Kujundjıc, S., Sokoviç, M. \& Couladis, M. (2003). Essential oil composition and antifungal activity of Foeniculum vulgare Mill. obtained by different distillation conditions. Phytotherapy Research: An International Journal Devoted to Pharmacological and Toxicological Evaluation of Natural Product Derivatives, 17, 368-371.

Mokrani, A. \& Madani, K. (2016). Effect of solvent, time and temperature on the extraction of phenolic compounds and antioxidant capacity of peach (Prunus persica L.) fruit. Separation and Purification Technology, 162, 68-76.

Mozaffarian, F. (2018). An identification key to the species of Auchenorrhyncha of Iranian fauna recorded as pests in orchards and a rewiev on the pest status of the species. Zootaxa, 4420, 475-501.

Muturi, J.E., Doll, K., Ramıres, J.L. \& Rooney, A. P. (2019). Bioactivity of wild carrot (Daucus carota, Apiaceae) essential oil against mosquito larvae. Journal of Medical Entomology, 56, 784-789.

Nast, J. (1987). The Auchenorrhyncha (Homoptera) of Europe. In Annales Zoologici, 40, 536-661.

Nicoletti, M., Serafini, M., Aliboni, A., D’Andrea, A. \& Mariani, S. (2010). Toxic effects of neem cake extracts on Aedes albopictus (Skuse) larvae. Parasitology Research, 107, 89-94.

Öztemiz, S. (2018). Ricania japonica (Hemiptera: ricaniidae): found in the western Black Sea, Turkey. Munis Entomology \& Zoology, 13, 326328. URL: https://docplayer.biz.tr/6123873Munis-entomology-zoology.html

Rauha, J.P., Wolfenderb, J.C., Saminen, J.P., Pihlaja, K., Hostettmann, K. \& Vuorela, H. (2001). Characterization of the polyphenolic composition 
of Purple Loosestrife (Lythrum salicaria). Zeitschrift für Naturforschung C, 56, 13-20.

Saeedi, M. \& Morteza-Semnani, K. (2009). Chemical composition and antimicrobial activity of the essential oil of Heliotropium europaeum. Chemistry of Natural Compounds, 45, 98-99.

Saeidnia, S., Sarkhail, P., Moradi-Afropoli, F., Goharı, A.R., Nikan, M., Mokhber-Defruzı, N., Amin, G.R. \& Hadjiakhoondi, A. (2014). GC/Mass analysis of the volatile compounds of $P$. hyrcanicum diethyl ether extract and GC profiling of some Iranian Polygonum species. Research Journal of Pharmacognosy, 1, 3-7.

Salem, M., Hussain, D., Rashid, R.H., Salem, H.M., Ghouse, G. \& Abbas, M. (2013). Insecticidal activities of two citrus oils against Tribolium castaneum (herbst). American Journal of Research Communication, 1, 67-74.

Sarıkaya, A.G. \& Fakir, H. (2017). Volatile Components of Leaves 2nd Flowers of Phlomis leucophracta P. H. Davis \& Hub.-Mor. and Phlomis lycia D. Don Grown in Goynuk Province (Antalya). Journal of Bartin Faculty of Forestry, 19, 69-73.

Sarker, S. \& Lim, U.T. (2018). Extract of Nicotiana tabacum as a potential control agent of Grapholita molesta (Lepidoptera: Tortricidae). PloS One, 13, e0198302.

Sefidkon, F. \& Khajavi, M.S. (1999). Chemical composition of the essential oils of two Salvia species from Iran: Salvia verticillata $\mathrm{L}$. and Salvia santolinifolia Boiss. Flavour and Fragrance Journal, 14, 77-78.

Shcherbakov, D.E. (2006). The earliest find of Tropiduchidae (Homoptera: Auchenorrhyncha), representing a new tribe, from the Eocene of Green River, USA, with notes on the fossil record of higher Fulgoroidea. Russian Entomological Journal, 15, 315-322.

Tabanca, N., Demirci, B., Aytaç, Z. \& Baser, K.H.C. (2017). The chemical composition of Salvia verticillata L. subsp. verticillata from Turkey. Natural Volatiles \& Essential Oils, 4, 18-28.

Taşdemir, D., Demirci, B., Dönmez, A.A., Başer, K.H.C. \& Rueedi, P. (2003). Analysis of the volatile components of five Turkish Rhododendron species by headspace solid-phase microextraction and GC-MS (HS-SPME-GCMS). Zeitschrift fuer Naturforschung, 58, 797803.

Usta, A., Yaylı, B., Kahrınman, N., Karaoğlu, S.A. \& Yayl,, N. (2012). Composition and antimicrobial activity of essential oil from the flower of Rhododendron luteum Sweet. Asian Journal of Chemistr,y 24, 1927-1930.

Yaylı, N., Tosun, G., Yaylı, B., Gündoğan, Z., Coşkuncelebi, K, \& Alpay K. Ş. (2016). Altitude variation in the composition of essential oils, fatty acid methyl esters, and antimicrobial activities of two subspecies of Primula vulgaris Grown in Turkey. Natural Product Communications, 11, 1505-1510. 